UDC 547.592.15; 547.312

\title{
SYNTHESIS AND PROPERTIES OF CYCLOHEXYL AMINES OF PROPARGYL SERIES
}

\author{
M.I.Shatirova, M.M.Movsum-zade*, U.Sh.Dzhafarova* \\ Institute of Polymer Materials, NAS of Azerbaijan \\ *A.Guliyev Institute of Chemistry of Additives, NAS of Azerbaijan \\ mshatirova@mail.ru
}

Received 01.07.2019

Accepted 14.02.2020

\begin{abstract}
The possibility of synthesis of the secondary and tertiary cyclohexylamines of propargyl series by interaction of cyclohexylamine with propargyl bromide in the presence of sodium hydroxide has been studied. It has been established that the synthesized secondary amine undergoes the various chemical reactions - hydrosilylation, diene condensation and addition reactions on reactive centers with formation of new derivatives. In particular, it has been shown that N-prop-2-yn-1-ylcyclohexylamine due to $\mathrm{N}-\mathrm{H}$ bond undergoes the reaction with acrylonitrile and epichlorohydrin (in the presence of boron trifluoride etherate) forming $\mathrm{N}$-cyanoethyl-N-prop-2-yn-1-ylcyclohexylamine and N-epoxy-N-prop-2-yn-1-ylcyclohexyl-amine, respectively. Under action of $10 \%$ aqueous solution of hydrochloric acid N-cyanoethyl-N-prop-2-yn-1ylcyclohexylamine is subjected to the hydrolysis forming unsaturated carboxylic acid. N-epoxy-N-prop-2yn-1-ylcyclohexylamine due to oxirane ring in interaction with concentrated sulphuric acid leads to the formation of the corresponding glycol of acetylene series and in the reaction with propargyl alcohol - to the formation of the corresponding ether-alcohol with two terminal acetylene bonds. The prepared compounds have been identified by the methods of IR-spectroscopy and NMR. The control over the course of the reaction was carried out by a method TLC on plates with aluminum oxide in the various systems of solvents, developer - iodine.
\end{abstract}

Keywords: cyclohexylamine, propargyl bromide, norbornadiene, hydrosilylation, carboxylic acid.

doi:

\section{Introduction}

Amine-containing compounds as synthons are widely used in the creation of new, diverse, highly effective physiologically and biologically active substances [1-3]. In this aspect, the preparation of amine-containing unsaturated compounds is of definite scientific and practical interest $[4,5]$. In particular, research in the field of synthesis and study of the properties of derivatives of alicyclic amines of the cyclohexane series indicates the promise of searching compounds with physiological and biological activity $[6,7]$. The introduction of a multiple bond, including acetylene, into the molecules of alicyclic amines contributes to an increase in biological activity, a decrease in toxicity and irritation of the compound [8].

\section{Experimental part}

The IR spectra of the synthesized compounds were recorded on a spectrophotometer ALPHA FT-IR ("BRUKER" Germany) on a
ZnSe crystal in the range of wave numbers 600 $4000 \mathrm{~cm}^{-1}$. The ${ }^{1} \mathrm{H}$ NMR spectra were recorded Fourier spectrometer FT-300 on a ("Bruker" Germany). Tetramethylsiloxsane (TMS) was used as an internal standard, and $\mathrm{CDCl}_{3}$ was the solvent.

N-Prop-2-yn-1-ylcyclohexylamine (I). $2.0 \mathrm{~g}(0.05 \mathrm{~mol})$ of sodium hydroxide, $2 \mathrm{ml}$ of water, $5.0 \mathrm{~g}(0.05 \mathrm{~mol})$ of cyclohexylamine were placed in a reaction flask and $6 \mathrm{~g}(0.05$ mol) of propargyl bromide were dropped in with vigorous stirring for 20 minutes. After $2 \mathrm{~h}$, the organic layer was separated; by distillation, compound I was obtained with a boiling range of $82-83^{0} \mathrm{C}(9 \mathrm{~mm}), n_{D}^{20}-1.4591, d_{4}^{20}-$ 0.8727 , yield $-73.6 \%$. Found, \%: C 78.60, H 11.12, $\mathrm{N}$ 10.13. $\mathrm{C}_{9} \mathrm{H}_{15} \mathrm{~N}$. Calculated, \%: C 78.77, H 11.02, N 10.21.

Similarly, N,N-diprop-2-yn-1-ylcyclohexylamine (II) was obtained from $5.0 \mathrm{~g}(0.05 \mathrm{~mol})$ 
of cyclohexylamine and $12 \mathrm{~g}(0.1 \mathrm{~mol})$ of propargyl bromide with a boiling range of 129 $130^{\circ} \mathrm{C}(10 \mathrm{~mm}), n_{D}^{20}-1.4831, d_{4}^{20}-0.9049$. Found, \%: C 82.21, H 9.60, N 8.10. $\mathrm{C}_{12} \mathrm{H}_{17} \mathrm{~N}$. Calculated, \%: C 82.30, H 9.79, N 8.00.

N-(3-Methyldiethylsilyl)prop-2-en-1-ylcyclohexylamine (III). In a $250 \mathrm{ml}$ flask, $6.6 \mathrm{~g}$ (0.05 mol) of compound (I) were placed and 0.1 $\mathrm{g}$ of a rhodium acetylacetonate dicarbonyl catalyst was added. While stirring, $5.1 \mathrm{~g}(0.05 \mathrm{~mol})$ of methyldiethylsilane was added and boiled at $55-60^{\circ} \mathrm{C}$ for 8 hours. After distillation, unreacted compounds were subjected to vacuum. $72.6 \%$ of the compound (III) was isolated: Boiling range $114-115^{0} \mathrm{C} \quad(9 \mathrm{~mm}), n_{D}^{20}-1.4580, d_{4}^{20}-$ 0.8270. Found, \%: C 70.37, H 12.10, Si 11.88, N 5.71. $\mathrm{C}_{14} \mathrm{H}_{29} \mathrm{NSi}$. Calculated, \%: C 70.29, H 12.22, Si 11.74, N 5.86.

\section{$\mathrm{N}$-(Methylenebicyclo[2.2.1]heptadiene-} 2,5-yl)-N-prop-2-yn-1-ylcyclohexylamine (IV). A mixture of $3.4 \mathrm{~g}(0.025 \mathrm{~mol})$ of the compound (I) and $1.6 \mathrm{~g}(0.025 \mathrm{~mol})$ of the CPD was heated in the presence of $0.05 \mathrm{~g}$ of hydroquinone in a sealed ampoule for 8-10 hours at $175-180^{\circ} \mathrm{C}$. At the end of the reaction, the reaction mixture was subjected to vacuum distillation. At the same time, unreacted starting components were distilled off, and the target product was subjected to repeated distillation and the adduct (IV) was separated from Boiling range $101-102^{0} \mathrm{C}(9 \mathrm{~mm}), n_{D}^{20}-1.4971, d_{4}^{20}-$ 0.9294. 68.6\%. Found, \%: C 82.60, H 10.56, N 6.82. $\mathrm{C}_{14} \mathrm{H}_{21} \mathrm{~N}$. Calculated, \%: $\mathrm{C} 82.72, \mathrm{H}$ 10.42 , N 6.90 .

\section{N-Cyanoethyl-N-prop-2-yn-1-ylcyclohe-} xylamine (V). With stirring, $5.7 \mathrm{~g}(0.1 \mathrm{~mol})$ of freshly distilled acrylic acid nitrile was added to $11.65 \mathrm{~g}(0.085 \mathrm{~mol})$ of compound (I). While there is an increase in the temperature of the reaction mixture. After the calculated amount of nitrile was added, the contents of the flask were heated for 7 hours at a temperature of $80-90^{\circ} \mathrm{C}$, and then fractionated. The resulting product $(\mathrm{V})$ has a batch of $121-122^{\circ} \mathrm{C}(9 \mathrm{~mm}), n_{D}^{20}-1.4711$, $d_{4}^{20}-0.9126 .78 .2 \%$. Found, \%: C 75.98, H
9.42, $\mathrm{N}$ 14.86. $\mathrm{C}_{12} \mathrm{H}_{18} \mathrm{~N}_{2}$. Calculated, \%: C 75.80, H 9.54, N 14.74.

\section{N-Epoxy-N-prop-2-yn-1-ylcyclohexyl-} amine (VI). $9.3 \mathrm{~g}(0.1 \mathrm{~mol})$ of epichlorohydrin was poured into the flask under reflux with stirring. $5.4 \mathrm{~g}$ ( $0.04 \mathrm{~mol})$ of compound (I) was added during 20 minutes at a temperature of $30^{\circ} \mathrm{C}$. The mixture was cooled to $5-7^{\circ} \mathrm{C}$ and treated with $9.6 \mathrm{~g}$ of $\mathrm{KOH}$ in $8 \mathrm{ml}$ of water. The organic layer was extracted with ether and dried over anhydrous $\mathrm{MgSO}_{4}$. Then the ether was distilled off, the "Edgeright" inhibitor (aldol- $\alpha$-naphthalene) was added and dispersed under vacuum. Compounds obtained (VI) with a batch of $147-148^{\circ} \mathrm{C}(9 \mathrm{~mm})$, $n_{D}^{20}-1.4871, d_{4}^{20}-0.9553$. Found, \%: C 74.43, $\mathrm{H}$ 9.86, N 7.17. $\mathrm{C}_{12} \mathrm{H}_{19} \mathrm{NO}$. Calculated, \%: C 74.57; H, 9.91; N 7.25.

Hydrolysis of N-cyanoethyl-N-prop-2yn-1-ylcyclohexylamine (VII). $9.5 \mathrm{~g}(0.05 \mathrm{~mol})$ of freshly distilled compound (V) were placed in a reaction flask equipped with a mechanical stirrer and reflux condenser. Then to the contents of the flask with vigorous stirring, $60 \mathrm{ml}$ of conc. sulfuric acid. When this was observed heating the reaction mixture and the formation of salt. The next day, the reaction mixture was stirred at a temperature of $50-60^{\circ} \mathrm{C}$ for $6-8$ hours, and then treated with water and $25 \mathrm{ml}$ of sulfuric ether was added. The aqueous layer was separated from the organic layer and the latter was dried over calcined $\mathrm{MgSO}_{4}$. After distilling off the solvent, (VII) was isolated from the residue by vacuum distillation with a batch of $100-101^{\circ} \mathrm{C}(2$ $\mathrm{mm}), n_{D}^{20}-1.5531, d_{4}^{20}-1.1190,74.4 \%$. Found, \%: C 68.73, H 9.28, N 6.54. $\mathrm{C}_{12} \mathrm{H}_{18} \mathrm{~N}_{2}$. Calculated, \%: C 68.86, H 9.15, N 6.69.

\section{N-Prop-2-yn-1-yl-N-(2-hydroxy-4-oxa-} hept-6-ynyl)cyclohexylamine (VIII). $\quad 8.4 \mathrm{~g}$ $(0.15 \mathrm{~mol})$ of propargyl alcohol containing 0.2 $\mathrm{ml}$ of boron trifluoride etherate with stirring and cooling $\left(0-5^{0} \mathrm{C}\right)$ added $12.6 \mathrm{~g}(0.065 \mathrm{~mol})$ of compound (VI). The reaction mixture was stirred for 5 hours at $22-25^{\circ} \mathrm{C}$. Then low-boiling substances were removed from the reaction mixture, and the residue was introduced dropwise into a flask containing a solution of diethyl ether and $15 \mathrm{~g}$ of finely divided caustic potassium. After 
that, the reaction mixture was stirred for another 5 hours at $13-15^{\circ} \mathrm{C}$. Then the solvent was removed and the substance (VIII) was isolated by distillation in vacuum with a batch of $120-121^{\circ} \mathrm{C}$ (2 mm), $n_{D}^{20}-1.5001, d_{4}^{20}-1.8926$. Found, \%: C 76.59, $\mathrm{H}$ 9.73, N 5.84. $\mathrm{C}_{15} \mathrm{H}_{23} \mathrm{NO}_{2}$. Calculated, $\%$ : C 76.55, H 9.85, N 5.95.

N-Prop-2-yn-1-yl-N-(2,3-dihydroxypropyl)cyclohexylamine (IX). $9.7 \mathrm{~g}(0.05 \mathrm{~mol})$ of epoxide (VI) was gradually added to $20 \mathrm{ml}$ of a $10 \%$ aqueous solution of sulfuric acid. Due to significant heat release, the reaction flask was cooled in the reaction processes with ice water. After a half hour of stirring, the reaction was complete. The aqueous solution was saturated with sodium chloride and extracted several times with ether and then with chloroform. After distilling off the solvent, diol (IX) was isolated by recrystallization with a $T_{\text {melt }} 88-89^{\circ} \mathrm{C}$ (19 mm). Yield 68.7\%. Found, \%: C 68.03, H 10.14, $\mathrm{N}$ 6.51. $\mathrm{C}_{12} \mathrm{H}_{21} \mathrm{NO}_{2}$. Calculated, \%: $\mathrm{C}$ 68.21, H 10.02, N 6.63.

\section{Results and discussion}

In this regard, and the continuation of the study [9-14] in this work was of some interest to study the possibility of synthesizing new functionally $\mathrm{N}$-substituted derivatives of the propargyl cyclohexylamines, as well as studying their certain chemical properties.

It was shown that the interaction of propargyl bromide with cyclohexylamine in the presence of sodium hydroxide, depending on the molar ratio of the reacting components, produces corresponding secondary and tertiary cyclohexylamines of the propargyl series (I, II) with a yield of 73.6 and $75.4 \%$, respectively:

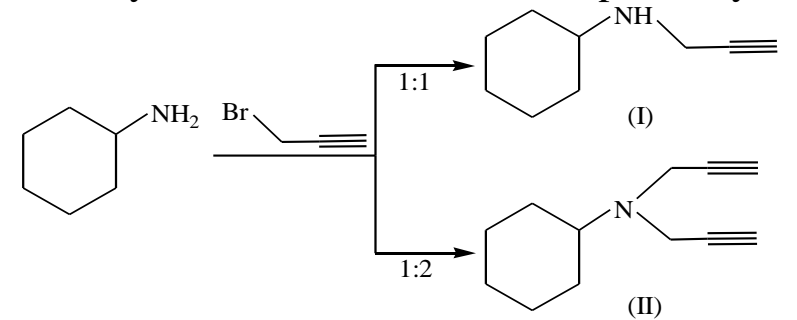

The obtained compounds (I, II) were characterized by the methods of IR spectroscopy, NMR and the of elemental analysis. In the IR spectrum of the synthesized compounds, there are characteristic absorption bands in the $2115-2135,2235,3300$, and $3350-3320 \mathrm{~cm}^{-1}$ regions, characteristic for $\mathrm{C} \equiv \mathrm{C}-\mathrm{H}, \mathrm{C}-\mathrm{N}$, and $\mathrm{N}-$ $\mathrm{H}$ bonds, respectively. In the NMR spectrum, a singlet signal with a chemical shift $\delta=4.41 \mathrm{ppm}$, characteristic of the proton of the secondary amino group $(1 \mathrm{H}, \mathrm{NH})$, is identified. Terminal acetylene protons of the propargyl fragment $(1 \mathrm{H}, \mathrm{HC} \equiv \mathrm{C}, J 2.3 \mathrm{~Hz})$ appear in the range $\delta=2.25-2.50 \mathrm{ppm}$ in the form of a triplet. Methylene proton of the fragment $\left(2 \mathrm{H}, \mathrm{NCH}_{2}, J 2.4\right.$ $\mathrm{Hz}$ ) are observed at $\delta=3.52 \mathrm{ppm}$ in the form of a doublet. The protons of the cyclohexane ring are identified in the region $\delta=1.40-1.80 \mathrm{ppm}$.

Synthesized cyclohexylamines of the acetylene series (I, II), due to the active terminal acetylene and $\mathrm{N}-\mathrm{H}$ bonds, enter into the reactions of hydrosilylation, diene condensation, additions, etc. forming new derivatives. In particular, it is shown that secondary amines enter into hydrosilylation reactions with methildiethylsilane (at $55-60^{\circ} \mathrm{C}$ ) in the presence of rhodium acetylacetonate dicarbonyl by a triple bond according to the Farmer rule with the formation of silicon-containing cyclic unsaturated amine in the trans structure (III). The diene condensation of the cyclohexylamine acetylene series with the cyclopentadiene proceeds (at 180$185^{\circ} \mathrm{C}$ ) also along a triple bond with the formation of the cyclohexylamine norbornadiene series (IV) with a yield of $68.6 \%$ according to the scheme:

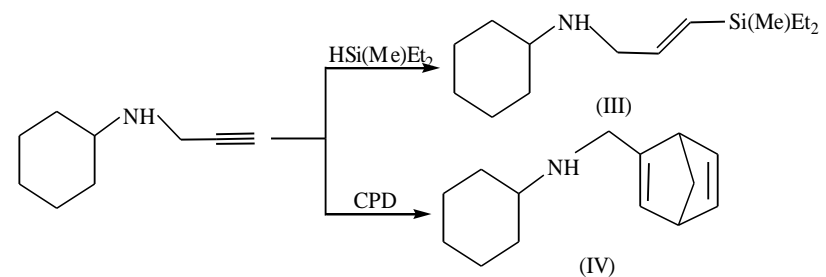

The IR spectrum of compound (III) absorption bands isobsent has no at 2135 and $3300 \mathrm{~cm}^{-1}$, characteristic of the terminal acetylene bond. In this case, the absorption bands at 1625 and $770 \mathrm{~cm}^{-1}$ are characteristic for the $\mathrm{HC}=\mathrm{CH}$ and $\mathrm{Si}-\mathrm{C}$ bonds, respectively. The presence of bands at 1290 and $965 \mathrm{~cm}^{-1}$ in the IR spectrum confirms the formation of the trans-isomer. In the ${ }^{1} \mathrm{H}-\mathrm{NMR}$ spectrum of compound (III), the signals of two protons at 
the double bond $(\mathrm{HC}=\mathrm{CH})$ with chemical shifts $\delta=4.82-4.94 \mathrm{ppm}$ are identified. and $\delta=5.50$ 5.64 ppm. Spin-Spin Coupling Constants (SSCC) of these protons, which are equal to 13.5-14.5 Hz, which is associated with their trans-structure. In the IR spectrum of compounds (IV) there are no bands belonging to the acetylene bond, and at the same time bands at $1645 \mathrm{~cm}^{-1}$, characteristic of $\mathrm{C}=\mathrm{C}$ bonds, were found.

The resulting N-propargylcyclohexylamine, thanks to the $\mathrm{N}-\mathrm{H}$ bond, also reacts with acrylonitrile and epichlorohydrin forming new derivatives of propargylcyclohexylamine. It was revealed that the reaction with acrylonitrile proceeds (at $80-90^{\circ} \mathrm{C}$ ) with the formation of $\mathrm{N}$ cyanoethyl-N-propargylcyclohexylamine with a yield of $78.2 \%$. The synthesis of $\mathrm{N}$ epoxy-N-propargylcyclohexylamine (VI) is carried out by the interaction of epichlorohydrin with N-propargylcyclohexylamine followed by dehydrochlorination of the resulting chlorohydrins by the reaction:

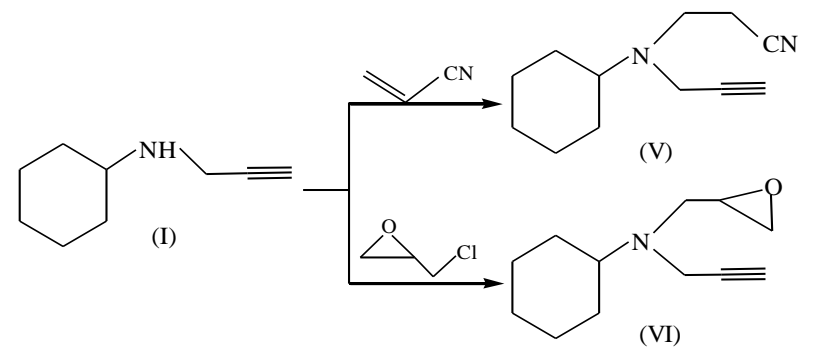

The reaction with epichlorohydrin proceeds at an equimolecular ratio of the reacting components at $20^{\circ} \mathrm{C}$ with a yield of $71.6 \%$.
In the IR spectrum of compounds (V), absorption bands at 3345 and $2245 \mathrm{~cm}^{-1}$, which are characteristic for $\mathrm{N}-\mathrm{H}$ and $\mathrm{C} \equiv \mathrm{N}$ bonds are identified. In the spectrum of compound (VI), along with the absorption bands characteristic for $\mathrm{N}-\mathrm{H}$, bands at 3065,1245 , and $950 \mathrm{~cm}^{-1}$, characteristic of the oxirane ring, were also found.

The synthesized cyanogen-containing propargylcyclohexylamine (V) under the action of a $10 \%$ aqueous solution of hydrochloric acid undergoes hydrolysis and the corresponding unsaturated carboxylic acid (VII) is formed with a yield of $74.4 \%$ according to the scheme:

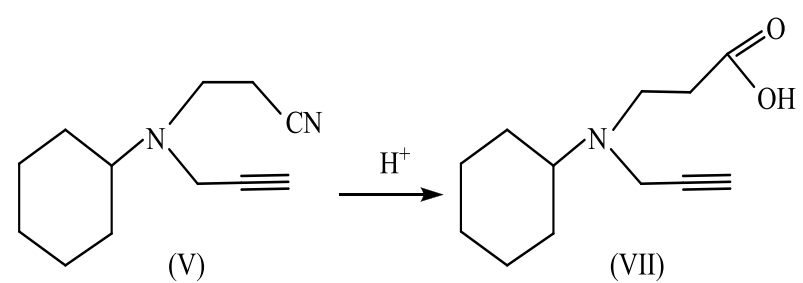

(V)

(VII)

In the IR spectrum of compound (VII) there is no band at $2245 \mathrm{~cm}^{-1}$, characteristic of the $\mathrm{C} \equiv \mathrm{N}$ bond. At the same time, absorption bands (1720 and $3460 \mathrm{~cm}^{-1}$ ) belonging to the carboxyl group were found.

It is established that epoxypropargylcyclohexylamine (VI), due to the oxirane ring, reacts with propargyl alcohol to form an ether alcohol with two terminal acetylene bonds (VIII). The epoxide (VI) obtained in the presence of a $10 \%$ aqueous solution of sulfuric acid undergoes hydrolysis on an oxirane cycle, with product formation of the corresponding glycol of the acetylene series (IX) in high yields:

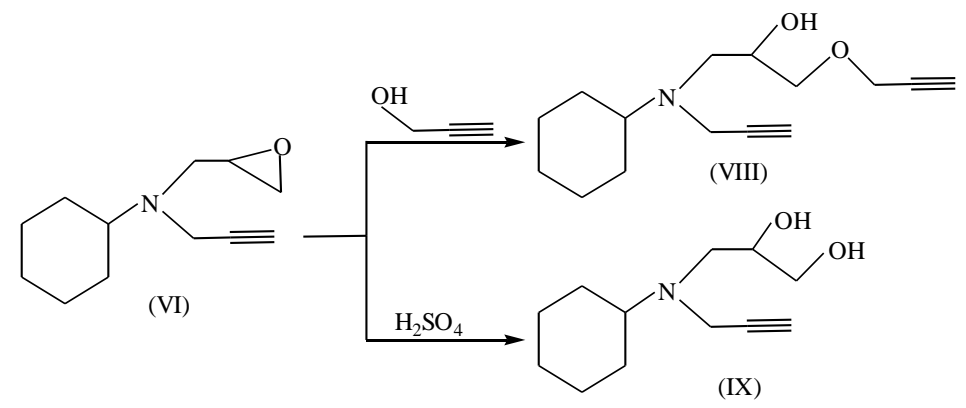


In the IR spectra of compounds (VIII, IX), the absorption bands characteristic for the oxirane ring $\left(3065,915 \mathrm{~cm}^{-1}\right)$ are absent. In this case, the bands in the region of 1100-1160 and $3450-3560 \mathrm{~cm}^{-1}$, which are characteristic of $\mathrm{C}-\mathrm{O}-\mathrm{C}$ and $\mathrm{O}-\mathrm{H}$ bonds, respectively, are identified.

Thus, as a result of the research, it was revealed that the synthesized amine-containing acetylenic compounds are highly reactive and can be used as modifiers of epoxy and polyester resins and as synthons for the production of various classes of organic compounds, including their biologically and physiologically active substances and their analogues.

\section{Conclusion}

1. A method has been developed for the synthesis of cyclohexylamines of the propargyl series based on the reaction of the interaction of propargyl bromide with cyclohexylamine in the presence of caustic potassium. It was shown that, depending on the molar ratio of the reacting components, the corresponding secondary and tertiary cyclohexylamines of the propargyl series with high yields are formed.

2 . The reaction of hydrosilylation of the synthesized cyclohexylamine propargyl series with methyldiethylsilane was studied and it was shown that the reaction proceeds at $55-60^{\circ} \mathrm{C}$ in the presence of rhodium acetylacetonate dicarbonyl along the terminal acetylene bond according to Farmer's rule with the formation of silicon-containing unsaturated cyclohexylamine trans-structure.

\section{Список литературы}

1. Shostakovskii M.F., Trofimov B.A., Atavin A.S., Lavrov V.I. Metody sinteza prostykh vinilovykh efirov, soderzhashchikh funktcionalnye gruppy i geteroatomy. Uspehi hi-mii. 1968. T. 37. № 11. S. 2070-2093.

2. Kasian L.I. Reaktcii alitciclicheskikh epoksidnykh soedinenii s azotsoderzhashchimi nucleofilnymi reagentami. Zhurn. org. him. 2004. T. 40. № 1. S. 11-42.
3. Kuharev B.F., Stankevich V.K., Climenko G.R. Vinilovye efiry aminospirtov i ikh proizvodnye. Uspehi himii, 1995. T. 64. № 6. S. 562-579.

4. Golovanov A.A., Odin I.S., Vologzhanina A.V., Bekin V.V., Nebritova A.B. Sintez 5-amino-1,5diarilpenta-2,4-dien-1-onov. Zhurn. org. him. 2014. T. 50. № 7. S. 963-967.

5. Sakura S., Mitani K., Hashimoto S., Morikawa K., Yasuda S., Koshinaka E., Kato H. Ito Y. Novel phenoxyalkylamine derivatives. VII. Synthesis and pharmacological activities of 2-alkoxy-5[(phenoxyalkylamino)alkyl]-benzenesulfonamide derivatives. Chem. Pharm. Bull. 1992. V. 40. No 6. P. 1443-1451.

6. Glushkov V.A., Piankova O.S., Anikina L.V., Viharev Iu.B., Feshina E.V., Shcliaev Iu.V, Tolstikov A.G. Sintez i neirotropnaia aktivnost proizvodnykh tciclogeksilamina. Him. farm. zhurnal. 2006. T. 40. № 6. S. 8-12.

7. Kosyhova L.A., Pikshilingaite Iu.-V.K., Zaks A.S., Rabotneykov Iu.M. Sintez i protivovospalitelnaia aktivnost diamidofosforilnykh proizvodnykh aminotciclogeksana. Him-farm. zh. 1996. № 5. S. 45-46.

8. Azerang P., Rezayan A.H., Sardari S., Kobarfard F., Bayat M., Tabib K. Synthesis and biological evaluation of propargyl acetate derivatives as antimycobacterial agents. DARU Journal of Pharmaceutical Sciences. 2012. V. 20. No 1. P. 90-95.

9. Kasian L.I., Palchikov V.A. Aminospirty s karkasnymi fragmentami. Sintez, reaktcii i puti ispolzovaniia. Zhurn. org. him. 2010. T. 46. № 1. S. 7-43.

10. Veliev M.G., Shatirova M.I., Alyev N.A., As-kerov O.V. Sintez i svoistva epoksiamino-propionitrilov allilovogo i propargilovogo riadov. Himicheskiye problemy. 2008. № 3. S. 519-523.

11. Veliev M.G., Shatirova M.I., Ibragimova A.I. Sintez i svoistva nepredelnykh aminospirtov. Funktcionalnye monomery i polimery ( $\mathrm{Sb}$. nauchn. tr. IPM NANA) Sumgaiyt: Bilik, 2012. S. 73-93.

12. Veliev M.G., Shatirova M.I., Ibragimova A.I. Sintez i svoistva nepredelnykh cyansoderzhashchikh aminov. Mat. VIII Mezhdunar. nauchno-prak. konf. Perspektivnye razrabotki nauki i tekhniki2013, Himiia i himicheskie tekhnologii, Rusnauka, 15-19 noiabria 2013. C. 98-100.

13. Veliev M.G., Shatirova M.I., Geidarova G.D., Alieva F.M. Aminsoderzhashchie atcetileny ingibitory kislotnoi korrozii stali. Korroziia: materialy, zashchita, 2016. № 5. S. 22-26.

14. Veliev M.G., Agaev N.M., Shatirova M.I., Cha-labieva A.Z., Geidarova G.D. Sintez diatceti-lenovykh efirov $\mathrm{s}$ terminalnymi atcetilenovymi sviaziami i issledovanie ikh $\mathrm{v}$ kachestve ingibitora stali v solianoi kislote. Zhurn. pricl. himii, 2010. T. 83. № 11. S. 1825-1829 


\title{
PROPARGIL SIRA TSIKLOHEKSILAMINLӘRIN SINTEZI VӘ XASSəLӘRI
}

\author{
M.İ.Şatirova, M.M.Mövsümzadə, U.Ş.Cəfərova
}

Tsikloheksilamininin propargil bromidlə kalium qələvisinin iştirakında qarşılıqlı təsiri zamanı propargil sıra ikili və üçlü tsikloheksilaminlərin sintezinin mümkünlüyü öyrənilmişdir. Müəyyən olunmuşdur ki, sintez olunmuş ikili aminlər reaksiyaqabilli mərkəzlər hesabına hidrosilillə̧̧mə, dien kondensasiyası və birləşmə reaksiyaları kimi müxtəlif kimyəvi reaksiyalara daxil olaraq yeni törəmələr əmələ gətirirlər. O cümlədən, N-prop-2-in-1-iltsikloheksilaminin N-H rabitənin hesabına akrilonitrillə və epixlorhidrinlə üçfülorlu bor efiratının itirakında reaksiyaya daxil olaraq müvafiq $\mathrm{N}$-sianetilN-prop-2-in-1-iltsikloheksilamin və N-epoksi-N-prop-2-in-1-iltsikloheksilamin əmələ gətirdiyi göstərilmişdir. N-sianetil-N-prop-2-in-1-iltsikloheksilaminin duz turşusunun 10\%-li sulu məhlulunun təsirindən hidrolizə uğrayaraq doymamış karbon turşusunun, $\mathrm{N}$-epoksi-N-prop-2-in-1-iltsikloheksilamin isə oksiran halqasının hesabına qatı sulfat turşusu ilə qarılıqlı təsirdən asetilen sıra qlikollların əmələ gəlməsinə gətirib çıxarır. Həmçinin, müəyyən olunmuşdur ki, N-epoksi-N-prop-2-in-1-iltsikloheksilaminin propargil spirti ilə reaksiyası zamanı iki terminal asetilen rabitəli müvafiq efirospirtlər əmələ gəlir. Alınmış birləşmələrin quruluşları IQ və NMR spektroskopiya üsullarının köməyi ilə eyniləşdirilmişdir. Reaksiyanın gedişatına nəzarət müxtəlif həlledici sistemlərdə alüminium oksid örtüklü plastinkalardan ibarət NTX üsulu ilə həyata keçirilmiş və aydınlaşdırıcı kimi yoddan istifadə olunmuşdur.

Açar sözlar: tsikloheksilamin, propargil bromid, norbornadien, hidrosilillaşmə, karbon turşusu.

\section{СИНТЕЗ И СВОЙСТВА ЦИКЛОГЕКСИЛАМИНОВ ПРОПАРГИЛОВОГО РЯДА}

\section{М.И.Шатирова, М.М.Мовсумзаде, У.Ш.Джафарова}

Изучена возможность синтеза вторичного и третичного циклогексиламинов пропаргилового ряда взаимодействием циклогексиламина с пропаргилбромидом в присутствии едкого калия. Установлено, что синтезированный вторичный амин вступает в различные химические реакции - реакции гидросилилирования, диеновой конденсации и присоединений по реакционноспособным центром с образованием новых производных. В частности показано, что N-проп-2-ин-1-илциклогексиламин, благодаря N-H связи, вступает в реакцию с акрилонитрилом и эпихлоргидрином в присутствии эфирата трехфтористого бора, образуя N-цианэтил-N-проп-2-ин-1илциклогексиламин и N-эпокси-N-проп-2-ин-1-илциклогексиламин, соответственно. Под действием $10 \%$-ного водного раствора соляной кислоты $\mathrm{N}$-цианэтил-N-проп-2-ин-1-илциклогексиламин подвергается гидролизу, образуя непредельную карбоновую кислоту. N-эпокси-N-проп-2-ин-1-илциклогексиламин благодаря оксирановому кольцу, при взаимодействии с концентрированной серной кислотой приводит к образованию соответствующего гликоля ацетиленового ряда, а в реакции с пропаргиловым спиртом - к образованию соответствующего эфироспирта с двумя терминальными ацетиленовыми связями. Полученные соединения идентифицированы методами ИК- и ЯМР-спектроскопии. Контроль за ходом реакции осуществляли методом ТСХ на пластинках с окисью алюминия в различных системах растворителей, проявитель - йод.

Ключевые слова: ичиклогексиламин, пропаргилбромид, норборнадиен, гидросилилирование, карбоновая кислота. 